\title{
Case Report \\ Clearance of the SARS-CoV-2 Virus in an Immunocompromised Patient Mediated by Convalescent Plasma without B-Cell Recovery
}

\author{
Maamoun Basheer ${ }^{1, *}$, Elias Saad ${ }^{1,2}$, Orly Laskar $^{3}{ }^{(D}$, Ofir Schuster $^{3}$, Hagai Rechnitzer ${ }^{4}(\mathbb{D}$, \\ Simona Zisman-Rozen ${ }^{4}$, David Azoulay ${ }^{2,5}$ and Nimer Assy ${ }^{1,2, *}$ \\ Internal Medicine Department, Galilee Medical Center, Nahariya 2210001, Israel; EliasS@gmc.gov.il \\ Azrieli Bar-Ilan Faculty of Medicine, Safad 2210001, Israel; DavidA@gmc.gov.il \\ 3 Department of Infectious Diseases, Israel Institute for Biological Research, Ness Ziona 7404905, Israel; \\ orlyl@iibr.gov.il (O.L.); schustero@gmc.gov.il (O.S.) \\ 4 The Clinical Microbiology Laboratory, Galilee Medical Center, Nahariya 2210001, Israel; \\ HagaiR@gmc.gov.il (H.R.); Zisman-Rozen@gmc.gov.il (S.Z.-R.) \\ 5 Hematology Unit and Clinical Laboratory, Galilee Medical Center, Nahariya 2210001, Israel \\ * Correspondence: maamon.basheer@mail.huji.ac.il (M.B.); nimera@gmc.gov.il (N.A.)
}

check for

updates

Citation: Basheer, M.; Saad, E.; Laskar, O.; Schuster, O.; Rechnitzer, H.; Zisman-Rozen, S.; Azoulay, D.; Assy, N. Clearance of the SARS-CoV-2 Virus in an Immunocompromised Patient Mediated by Convalescent Plasma without B-Cell Recovery. Int. J. Mol. Sci. 2021, 22, 8902. https:// doi.org/10.3390/ijms22168902

Academic Editor: Edwin Leeansyah

Received: 27 June 2021

Accepted: 17 August 2021

Published: 18 August 2021

Publisher's Note: MDPI stays neutral with regard to jurisdictional claims in published maps and institutional affiliations.

Copyright: (c) 2021 by the authors. Licensee MDPI, Basel, Switzerland. This article is an open access article distributed under the terms and conditions of the Creative Commons Attribution (CC BY) license (https:// creativecommons.org/licenses/by/ $4.0 /)$.

\begin{abstract}
Coronavirus disease (COVID-19) is a contagious disease caused by the severe acute respiratory syndrome coronavirus 2 (SARS-CoV-2). This case report presents a patient who had difficulty eradicating the corona virus due to being treated with Rituximab, which depletes B lymphocyte cells and therefore disables the production of neutralizing antibodies. The combined use of external anti-viral agents like convalescent plasma, IVIG and Remdesivir successfully helped the patient's immune system to eradicate the virus without B-cell population recovery. In vitro studies showed that convalescent plasma is the main agent that helped in eradicating the virus.
\end{abstract}

Keywords: immunocompromised; SARS-COV-2; pneumonia; T lymphocytes

\section{Introduction}

Coronavirus disease (COVID-19) is contagious and is caused by the severe acute respiratory syndrome coronavirus 2 (SARS-CoV-2) [1]. Rituximab, an anti-CD20 monoclonal antibody, is one of the main treatments for B-cell malignancies and auto-immune diseases [2]. It acts by depleting normal cells (as well as pathogenic B cells) while sparing other plasma cells and hematopoietic stem cells [2,3]. This medication prolongs B-cell depletion, which impairs the adaptive immune response and the ability to produce neutralizing antibodies. Patients treated with Rituximab are at a higher risk for prolong severe forms of COVID-19 [4-7].

This case report presents a patient treated with Rituximab, and discusses the specific interventions conducted to eradicate the virus.

\section{Material and Methods}

\subsection{Convalescent Plasma}

Convalescent plasma donations were tested for the presence of anti-SARS-CoV-2 IgG using an ELISA assay with the spike protein as an antigen. The titer of anti-SARS -CoV-2 IgG was more than 1:1000. The protocol of the Israeli ministry of health is two units of convalescent plasma for COVID-19 patients [8].

\subsection{Flow Cytometry Analysis of Leucocyte Differentials and Lymphocytic Subsets}

For measuring lymphocyte sub-set proportions, $50 \mu \mathrm{L}$ of whole blood was incubated with an antibody mixture containing: Pacific-Blue conjugated anti-human CD7 (Beckman Coulter Inc., Carlsbad, CA, USA), PE-Cy7 conjugated anti-human CD45 (Beckman Coulter 
Inc., Carlsbad, CA, USA), PE-Cy5, conjugated anti-human CD56 (Beckman Coulter Inc., Carlsbad, CA, USA), ECD conjugated anti-human CD3 (Beckman Coulter Inc., Carlsbad, CA, USA), PE conjugated anti-human CD8 (Beckman Coulter Inc., Carlsbad, CA, USA) and FITC conjugated anti-human CD4 and CD19 (Beckman Coulter Inc., Carlsbad, CA, USA). The samples were incubated for $10 \mathrm{~min}$ at room temperature, and underwent red blood cell lysis via VersaLyse solution (Beckman Coulter Inc., Carlsbad, CA, USA)for an additional $10 \mathrm{~min}$. The total lymphocytes count of the patients were determined by the system XN1000 hematology analyzer (Sysmex Corporation, Kobe, Japan) and recorded. The results were read by a Beckman Coulter Navios flow cytometer. The total leucocytes were recorded, and the percentages of the lymphocyte subsets from the total gated lymphocytes were also recorded.

\subsection{COVID-19 Infection Status as Detected by the Nasopharyngeal RT-PCR Test and the Cytopathic Effect}

Following nasal and throat sampling, viral swabs were inserted into refrigerated transfer buffer containing tubes (Copan). Tubes containing the swabs were vortexed for $1 \mathrm{~min}$. Two $\mathrm{ml}$ of the buffer were transferred to a new $15 \mathrm{~mL}$ tube and centrifuged $(5000 \times g$, $5 \mathrm{~min}, 4^{\circ} \mathrm{C}$ ), and the supernatant was transferred through a $0.22 \mu \mathrm{m}$ filter. Vero E6 (ATCC CRL-1586TM), were cultured in DMEM supplemented with 10\% fetal bovine serum (FBS), MEM non-essential amino acids, $2 \mathrm{mM}$ L-Glutamine, 100 Units $/ \mathrm{mL}$ Penicillin, $0.1 \mathrm{mg} / \mathrm{mL}$ streptomycin, 12.5 Units/mL Nystatin (Biological Industries, Beit Haemek, Israel). Each supernatant sample was added in duplicates to cells monolayers in 12-well plates (Costar; $0.2 \mathrm{~mL} /$ well) for $1 \mathrm{~h}$, followed by the addition of $2 \mathrm{~mL}$ MEM containing $2 \%$ FBS, MEM non-essential amino acids, $2 \mathrm{mM}$ L-Glutamine, 100 Units $/ \mathrm{mL}$ Penicillin, $0.1 \mathrm{mg} / \mathrm{mL}$ streptomycin, 12.5 Units/mL Nystatin and $0.15 \%$ sodium bicarbonate (Biological Industries, Beit Haemek, Israel). Plates were further incubated at $37^{\circ} \mathrm{C}, 5 \% \mathrm{CO}_{2}$ for 5 days. SARSCoV-2 (GISAID accession EPI_ISL_406862), kindly provided by Bundeswehr Institute of Microbiology, Munich, Germany, was used as positive control at a concentration of $60 \mathrm{pfu} / \mathrm{mL}$. Cytopathic effect (CPE) was microscopically determined [9]. To confirm that the cytopathic effect was due to SARS-Cov-2, a RT-real time PCR for the virus was performed on cell supernatant. The assay was conducted on days 41, 54 and 95 after the first positive corona test.

RT-PCR and PCR were used for SARS-CoV-2 detection. Viral RNA was extracted from nasopharyngeal samples using the QIAamp Viral RNA Mini Kit (Qiagen) according to the manufacturer's instructions. RT-PCR and PCR were performed subsequently with a one-step real time RT-PCR kit containing primers and probes targeting the ORF1b and a positive internal reference gene. Reaction system and amplification conditions were performed according to the manufacturer's specifications (Wuhan BGI Biotechnology Co. Ltd., Wuhan, China). The result was considered valid only when the cycle threshold (Ct) value of the reference gene was $\leq 32$. The result was considered positive for $2019-\mathrm{nCoV}$ when the $\mathrm{C} t$ value of the ORF1b target gene was $\leq 36$ (borderline result was determined when the $\mathrm{Ct}$ value of the ORF1b target gene was $>36$ but $\leq 40$ and negative when ORF1b Ct was above 40 or not detected).

\subsection{In Vitro Studies of the Efficiency of Different Agents to Eradicate the SARS-CoV-2 Virus}

SARS-CoV-2 viruses (60 PFU/well) were treated with different materials (Remdesivir $100 \mu \mathrm{g} / \mathrm{mL}$, Ivermectin $3 \mu \mathrm{g} / \mathrm{mL}$, IVIG $20 \mathrm{mg} / \mathrm{mL}$ or convalescent plasma $50 \mu \mathrm{L} /$ well). The blood of the patient was drained to an EDTA tube. The wells were then incubated with $50 \mu \mathrm{L}$ buffy coat, the fraction of an anti-coagulated blood sample that contained most of the white blood cells of the patient. Each mixture was transferred to Vero E6 cells, followed by 5 days of incubation. The cytopathogenic effect of the intact virus was measured in all study groups. 


\subsection{Ethics}

This work was done according to the instructions of the local committee of Helsinki for human Studies. The patient signed a form concern confirming the publication of this work.

\section{Results}

\subsection{Clinical and Labortory Monitoing of the Pateint}

The patient was infected with the SARS-CoV-2 virus on day 1 . On day 25, he came to the emergency room with general weakness, cough and dyspnea. The RT-PCR from a nasopharyngeal sample was positive for corona virus. While hospitalized in a designated COVID-19 ward, the patient was treated with two units of convalescent plasma, systemic steroids, anticoagulants and vitamin D, a known COVID-19 treatment protocol, with a good response. Throughout the hospitalization, the patient was hemodynamically stable with normal saturation levels on room air (Figure 1A). Radiographic imaging showed about 50\% of lung injury Figure 1B). He was discharged on day 41 with no need for supplementary oxygen.

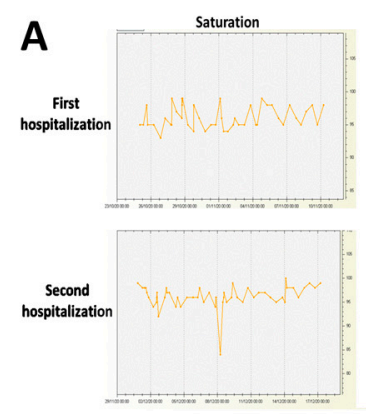

B

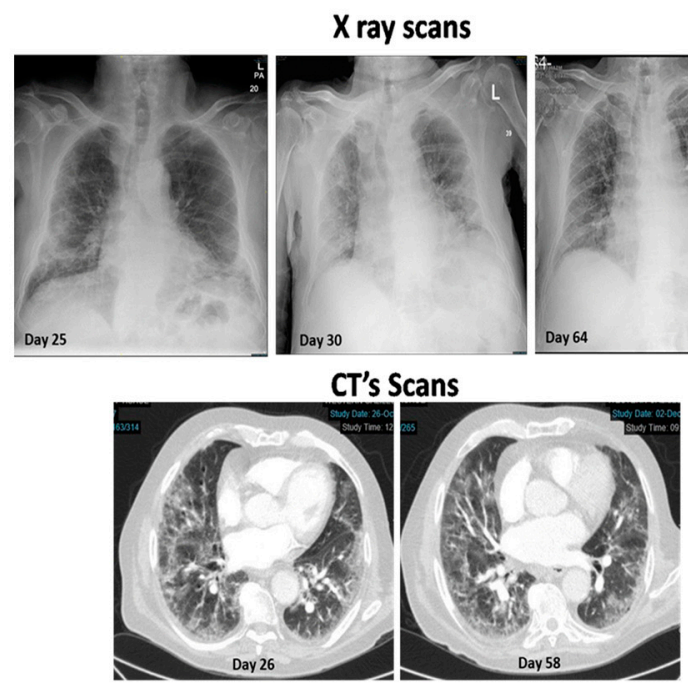

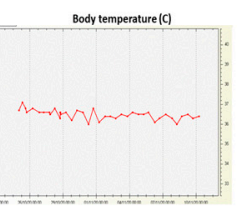
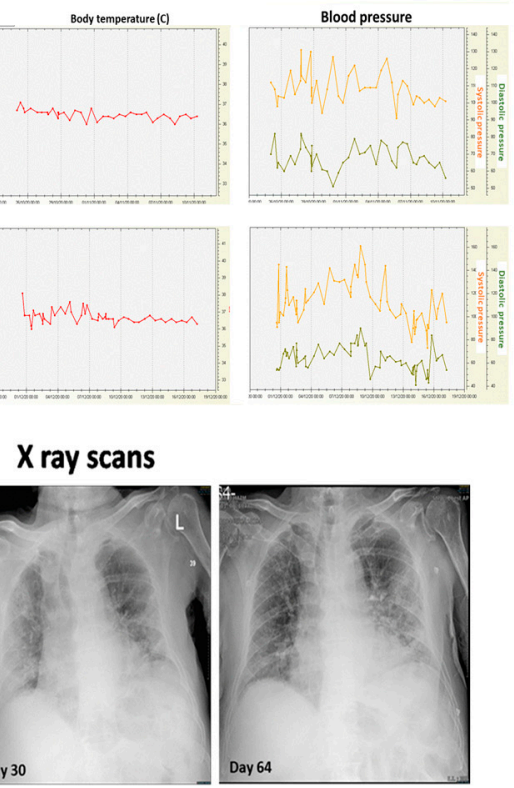

\begin{tabular}{|c|c|c|c|c|}
\hline & \multicolumn{2}{|c|}{ First admission } & \multicolumn{2}{|c|}{ Second admission } \\
\hline to & On admission & On discharge & $\begin{array}{c}\text { On } \\
\text { admission }\end{array}$ & On discharge \\
\hline $\mathrm{Hg}(\mathrm{g} / \mathrm{dl})$ & 8.5 & 10.2 & 7.6 & 8.4 \\
\hline WBC (x103/ul) & 2.7 & 4.33 & 2.7 & 3.8 \\
\hline PLT $\left(x 10^{3} / \mu \mathrm{l}\right)$ & 96 & 137 & 95 & 143 \\
\hline $\begin{array}{l}\text { Absolute Neutrophile } \\
\text { count }\left(\times 10^{3} / \mu l\right)\end{array}$ & 2.23 & 3.6 & 2.46 & 3.34 \\
\hline $\begin{array}{l}\text { Absolute Lymphocytes } \\
\text { count }\left(\times 10^{3} / \mu \mathrm{l}\right)\end{array}$ & 0.11 & 0.21 & 0.10 & 0.10 \\
\hline Phosphor (mg/dl) & 2.7 & 3.1 & 1.9 & 2.8 \\
\hline Potassium (mmol/l) & 4.3 & 4.5 & 3.87 & 4.03 \\
\hline Sodium (mmol/l) & 133 & 135 & 137 & 132 \\
\hline BUN (mg/dl) & 18.7 & 22.1 & 11.8 & 26.4 \\
\hline Magnesium (mg/dl) & 2.17 & 2.05 & 1.93 & 1.85 \\
\hline Albumin (g/dl) & 3.35 & 3.76 & 2.6 & 3.2 \\
\hline Creatinine (mg/dl) & 1.05 & 0.81 & 0.96 & 1.38 \\
\hline $\mathrm{GFR}(\mathrm{ml} / \mathrm{min} / 1.73 \mathrm{~m} 2)$ & 90 & 83 & 87 & 81 \\
\hline $\begin{array}{l}\text { C-Reactive protein } \\
\text { (mg/l) }\end{array}$ & 118 & 34 & 55 & 21 \\
\hline $\mathrm{HDL}$ (mg/dl) & 23.7 & 20.1 & 21.8 & 19.6 \\
\hline AST (U/L) & 47 & 32 & 18.6 & 26 \\
\hline ALT (U/L) & 14 & 34 & 7 & 6 \\
\hline GGT (U/L) & & & 64 & \\
\hline LDH (U/L) & 235 & 202 & 173 & 247 \\
\hline Fibrinogen (mg/dl) & 698 & & 675 & \\
\hline D-dimer (ng/ml) & 1053 & & 1011 & \\
\hline INR & 1.3 & & 1.2 & \\
\hline Ferritin (ng/ml) & 1130 & 1131 & 907 & \\
\hline
\end{tabular}

Figure 1. (A) $\mathrm{O}_{2}$ saturation, body temperature, systolic and diastolic blood pressure. The upper and lower panels relate to the first and the second hospitalization, respectively. (B) Upper panel: Posterior anterior chest radiograph showing bilateral patchy lung consolidation in a peripheral distribution pattern on days 25, 30 and 64 after the first positive corona test. Lower panel: Unenhanced, thin-section CT performed on day 26 after the first positive corona test showing bilateral ground-glass attenuations with subsequent deterioration in the second hospitalization on day 58. (C) Complete blood count and bio-chemical results of the patient during the first and the second hospitalizations upon admittance and discharge.

On day 61, the patient returned to the hospital with a fever. Laboratory tests showed signs of inflammation. Repeated SARS-CoV-2 RT-PCR were positive, causing concern for a continuous persistent COVID-19 infection. The patient was therefore, readmitted to the COVID-19 ward. To achieve virus eradication, the patient underwent a second regiment of Remdesivir (10-day course), four units of convalescent plasma, $120 \mathrm{~g}$ of intravenous 
immunoglobulin and one dose of ivermectin $(15 \mathrm{mg})$. The patient improved and was discharged within 10 days.

The complete blood count of the patient showed thrombocytopenia and severe lymphopenia (Figure 1C). Biochemical analysis showed stable plasma electrolyte concentrations. Inflammatory parameters (C-reactive protein, ferritin, D-dimer and fibrinogen) were increased upon admission. A decrease in these parameters was noted once treatment was presented (Figure 1C).

\subsection{Analysis of Leucocytes Differential and Lymphocyte Subsets Proportion by Flow Cytometry}

Analysis of the leucocyte differential and lymphocyte subset proportion via flow cytometry showed a depletion of B-cells $(<1 \%)$ upon admission with no recovery after the intervention. However, T-cells were increased after intervention from $73 \%$ to $83.5 \%$. The CD4, CD8 and NK cell (CD3-/CD56+) populations also increased after the treatment. The $\mathrm{CD} 4+/ \mathrm{CD} 8+$ ratio was low before the intervention, with no further changes (Figure 2).

\begin{tabular}{|c|c|c|}
\hline & Before & After \\
\hline Absolute White blood cells (WBC) $\left(x 10^{3} / \mu l\right)$ & 2670 & 3090 \\
\hline \% lymphocytes (of total WBC) & 1.50 & 14.9 \\
\hline \%Monocytes(of total WBC) & 6 & 5.8 \\
\hline \%Granulocytes (of total WBC) & 92.10 & 77 \\
\hline Absolute Lymphocyte cells $(\mathrm{CD} 56+)\left(\times 10^{3} / \mu \mathrm{l}\right)$ & 40 & 460 \\
\hline B cell (CD19+) (\%of total lymphocytes) & $0.1(0.8)$ & $1.8(0.4)$ \\
\hline T cell (\%of total lymphocytes) & $30(73.4)$ & $384(83.5)$ \\
\hline CD4 (\%of total T cells) & $3(9.5)$ & $69(18.2)$ \\
\hline CD8 (\%of total T cells) & 27 (89.7) & 295 (77.1) \\
\hline NK CELL (CD3-/CD56+) & & \\
\hline (\%of total lymphocytes) & $8(20)$ & $48(10.5)$ \\
\hline CD4+/CD8+ & 0.3 & 0.5 \\
\hline
\end{tabular}

Figure 2. Analysis of leucocytes differential and lymphocyte subsets proportion by flow cytometry.

3.3. COVID-19 Infection and Immunity Status as Detected by a Nasopharynx COVID-19 PCR Test and Viral Culture

COVID-19 infection and immunity status were tested. RT-PCRs were performed on nasal and throat samples on days 1, 25, 41, 54, 60, 75, 95 and 136, after the first positive corona test was done. To confirm that the virus was alive and intact, the viral cytotoxic effect was tested on a VERO cell culture.

The results showed that the patient was positive for the Corona virus (days 1, 25, 41, 54 and 60) until intervention as shown also by the cytotoxic culture assay in days 41 and 54. Negative SARS-CoV-2 RT PCR results were initially achieved after the intervention (days 75, 95 and 136). A cytotoxic culture assay confirmed the eradication of the virus after intervention (day 95). No SARS-CoV-2 antibodies were found (Figure 3). Viral genetic sequencing showed that it was probably a wild strain and less suitable for variant sequencing. 


\begin{tabular}{|c|c|c|c|c|}
\hline $\begin{array}{c}\text { Days after First } \\
\text { Positive COVID- } \\
19 \text { Test }\end{array}$ & $\begin{array}{c}\text { Nasopharynx } \\
\text { COVID-19 PCR Test Cycle } \\
\text { Threshold (CT)) }\end{array}$ & $\begin{array}{c}\text { COVID-19 } \\
\text { Antibodies }\end{array}$ & $\begin{array}{c}\text { Intact Virus in } \\
\text { Viral Culture }\end{array}$ & $\begin{array}{c}\text { PCR (COVID-19) from Viral } \\
\text { Culture }\end{array}$ \\
\hline 1 & $+(26)$ & - & & \\
\hline 25 & $+(17)$ & - & & + \\
\hline 41 & $+(28)$ & - & + & + \\
\hline 54 & $+(19)$ & - & + & \\
\hline 60 & $+(30)$ & - & & \\
\hline 75 & - & - & & \\
\hline 95 & - & - & - & \\
\hline 136 & - & & & \\
\hline
\end{tabular}

Figure 3. COVID-19 infection and immunity status as detected by nasopharynx COVID-19 PCR tests and viral culture. A PCR test of nasal and throat samples showed positive test on days 1, 25, 41, 54 and 60 with a low cycle threshold (CT). Negative results were visible on days 75, 95 and 136. Cell cultures showed intact viruses on days 41 and 54 . Negative cell culture for the corona virus was verified on day 95 after the completed course of the treatment.

\subsection{In Vitro Studies: Different Agents' Effects on SARS-CoV2 Cytotoxic Effect Using Vero E6 Cells}

In vitro studies confirmed that convalescent plasma and Remdesivir successfully eradicated the virus. Convalescent sera or Remdesivir were shown to confer protection against the cytopathic effect, while CPE was observed in all other treatments (Figure 4). The PCR results showed low or absent viral loads in convalescent plasma or Remdesivir samples. These data support the CPE observations, and demonstrates that CPE formation was due to SARS-CoV-2 presence (Figure 4).

All substances (Remdesivir, Ivermectin, IVIG and convalescent plasma) without patient blood cells were added to Vero E6 cells with or without SARS-CoV-2, and their effect on the cells was tested. It was found that in the absence of the virus, no CPE was observed using any of the substances. In the presence of SARS-CoV-2 and without patient blood cells, CPE observed in the Ivermectin and IVIG samples, whereas in the Remdesivir and convalescent plasma samples, minimal CPE was observed. The RT-PCR results for these samples showed that there was a significant eradication of the virus; however, at slightly lower CT levels (33 and 35, respectively) compared to these samples in the presence of white blood cells from the patient. This suggests that the patient immune system with convalescent plasma synergically eradicate the virus. 
A
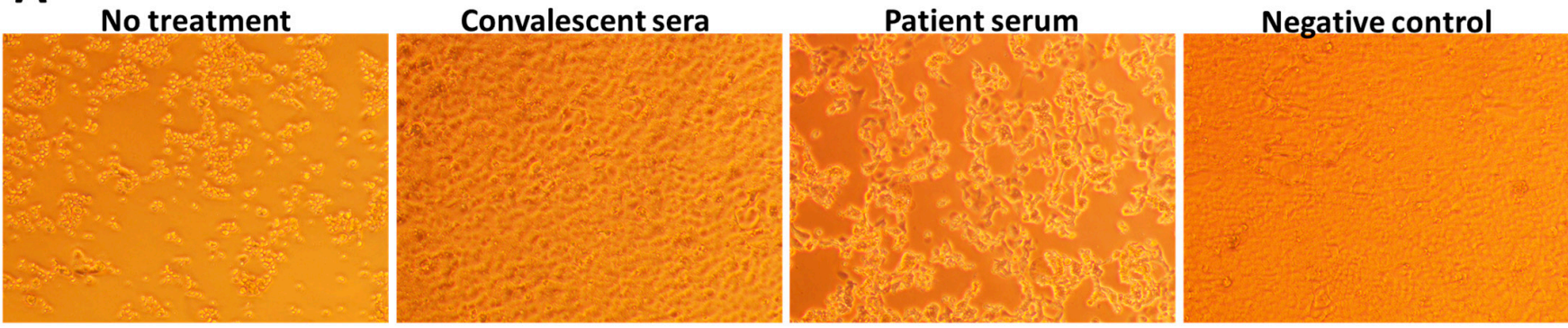

\section{$3 \mu \mathrm{g} / \mathrm{ml}$ Ivermectin}

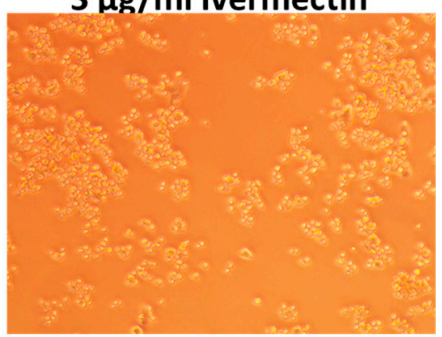

B

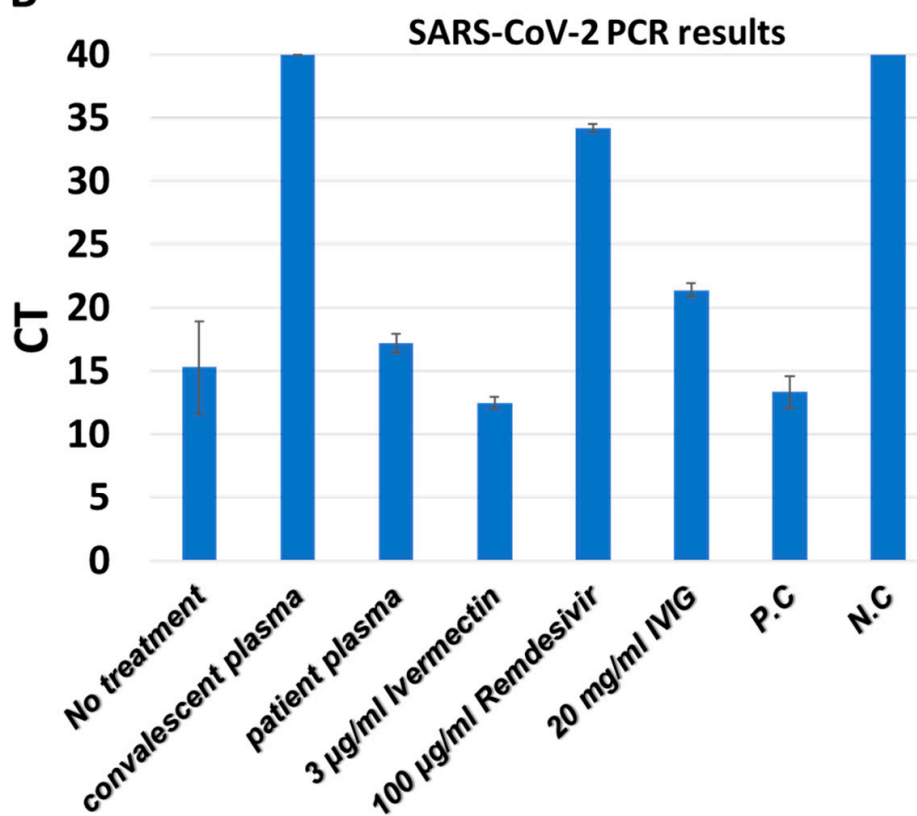

$20 \mathrm{mg} / \mathrm{ml} \mathrm{IVIG}$
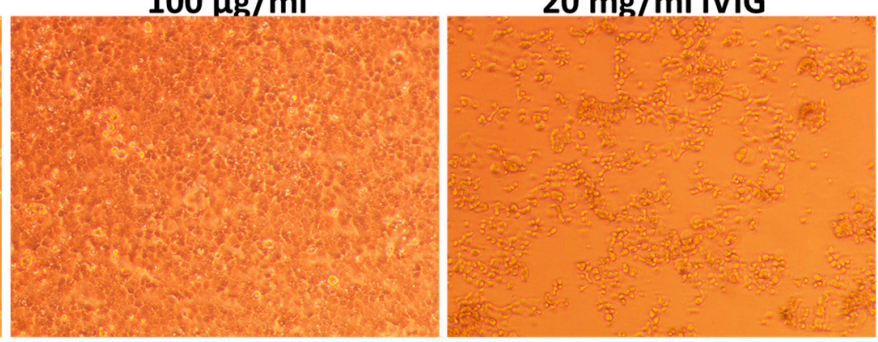

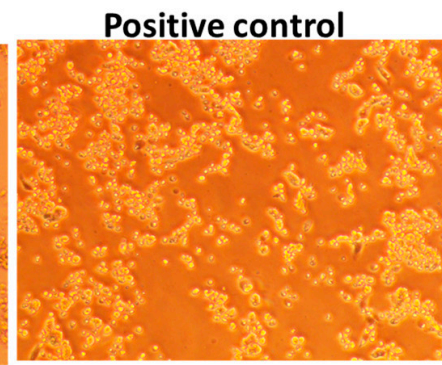

C

\begin{tabular}{|c|c|c|}
\hline Treatment & CPE & PCR (Ct) \\
\hline No treatment & + & 15.3 \\
\hline $\begin{array}{c}\text { Convalescent } \\
\text { plasma }\end{array}$ & - & 40.0 \\
\hline Patient serum & + & 17.2 \\
\hline Ivermectin & + & 12.5 \\
\hline Remdesivir & - & 34.2 \\
\hline IVIG & + & 21.4 \\
\hline P.C & + & 13.3 \\
\hline N.C & - & 40.0 \\
\hline
\end{tabular}

Figure 4. In vitro studies confirming that convalescent plasma and Remdesivir successfully eradicated the virus. (A): SARSCoV-2 viruses (60 PFU/well) were treated with different agents in the presence of white blood cells from the immunodeficient patient. Each mixture was transferred to Vero E6 cells, followed by five days incubation to the formation of CPE. Representative images for each treatment are presented. (B): PCR results of SARS-CoV-2 identification from each treatment are presented (averages of three triplicates with their SD). P.C: positive control. N.C.: negative control. (C): Summary of CPE and PCR results for each treatment. +/ - presence/absence of CPE.

\section{Discussion}

This case report presents a patient treated with Rituximab, which depletes B lymphocyte cells and therefore disables the production of neutralizing antibodies, creating difficulties in eradicating the corona virus.

On day one, the infected patient was asymptomatic. He presented to the ER on day 25 with general weakness. His first hospitalization period extended to 16 days. The patient was treated with two units of convalescent plasma, systemic steroids, anti-coagulants 
and vitamin D, a known COVID-19 treatment protocol (as recommended by the Israeli ministry of health) with good response. He was discharged on day 41 with no need for supplementary oxygen. The RT-PCR assay from a nasopharyngeal sample was still positive, while anti-SARS specific- coV-2 IgG were negative.

Due to the fact that the patient was treated with Rituximab, he was immunocompromised, and due to the positive cell culture test, the patient was still contagious and was indicated for quarantine. From day 41 through day 61, the patient was quarantined alone at home. During this period, the patient felt good, with no need for supplementary oxygen. Another RT-PCR test taken on day 54, with positive results, with no SARS-CoV-2 antibodies. A cell culture test also showed that the patient still had live intact virus particles within the cells.

At day 61, the patient returned to the hospital with a fever. Repeated RT-PCR assays were positive, causing concern for a continuous persistent COVID-19 infection. During this hospitalization stay, the patient received a second course of Remdesivir (10-day course), four units of convalescent plasma, $120 \mathrm{~g}$ of intravenous immunoglobulin, as recommended by some studies [10-12] and one dose of Ivermectin (15 mg) [13]. He improved under this treatment. On discharge day (day 77), an RT-PCR assay from a nasopharyngeal swab was negative and no Coronavirus antibodies were found. Furthermore, a cell culture test was repeated laterally on day 95, with no presence of live intact viruses. It should be noted that analysis of whole blood samples taken both on admission and discharge, showed a limited B lymphocyte population (about 1\%).

The patient was positive for COVID-19 for 75 days, confirmed by a special cell culture test that showed evidence of intact live virulent viruses with cytotoxic abilities. No antiSARS-CoV-2 IgG antibodies were identified. A specific intervention, which included convalescent plasma and another extended course of Remdesivir, eventually eradicated the virus. Remdesivir and convalescent plasma are anti-viral agents, but each works through different mechanisms. Remdesivir is known to inhibit the replication of the virus. It works as a nucleoside analog and inhibits the RNA-dependent RNA polymerase. On the other hand, convalescent plasma contains SARS-CoV-2 antibodies, which work synergically with the patient immune system in order to eradicate the virus.

Rituximab treated patients need passive immunotherapy to eradicate viruses. The supply of these antibodies by convalescent plasma is critical for the good function of the immune system mediating viral clearance. The immune system, with B cell depletion, could eradicate the SARS-CoV-2 virus. These results were also previously presented by Thomas Hueso et al. [10]. This case study suggests that T cells and other cells in the innate system work synergistically with exogenous antibodies in eradicating the SARS-CoV-2 virus.

In conclusion, this case report presents a patient treated with Rituximab, which depletes B lymphocyte population and, therefore, disables the production of neutralizing antibodies. The combined use of external anti-viral agents such as convalescent plasma and Remdesivir, helped the patient's immune system in eradicating the virus, with no need for B-cell population recovery.

Author Contributions: All authors contribute equally in this paper. All authors have read and agreed to the published version of the manuscript.

Funding: This research received no external funding.

Institutional Review Board Statement: The study was conducted according to the guidelines of the Declaration of Helsinki, and approved by the Institutional Review Board.

Informed Consent Statement: Informed consent was established and signed.

Data Availability Statement: All data from patient file.

Conflicts of Interest: The authors declare no conflict of interest. 


\section{References}

1. Richardson, S.; Hirsch, J.S.; Narasimhan, M.; Crawford, J.M.; McGinn, T.; Davidson, K.W.; Northwell COVID-19 Research Consortium. Presenting characteristics, comorbidities and outcomes among 5,700 patients hospitalized with COVID-19 in the New York City area. JAMA 2020, 323, 2052-2059. [CrossRef] [PubMed]

2. Salles, G.; Barrett, M.; Foà, R.; Maurer, J.; O’Brien, S.; Valente, N.; Maloney, D.G. Rituximab in B-cell hematologic malignancies: A review of 20 years of clinical experience. Adv. Ther. 2017, 34, 2232-2273. [CrossRef] [PubMed]

3. Hawker, K.; O'Connor, P.; Freedman, M.S.; Calabresi, P.A.; Antel, J.; Simon, J.; Hauser, S.; Waubant, E.; Vollmer, T.; Panitch, H.; et al. Rituximab in patients with primary progressive multiple sclerosis: Results of a randomized double-blind placebo controlled multicenter trial. Ann. Neurol. 2009, 66, 460-471. [CrossRef] [PubMed]

4. Tepasse, P.R.; Hafezi, W.; Lutz, M.; Kühn, J.; Wilms, C.; Wiewrodt, R.; Sackarnd, J.; Keller, M.; Schmidt, H.H.; Vollenberg, R. Persisting SARS-CoV-2 viraemia after rituximab therapy: Two cases with fatal outcome and a review of the literature. Br. $J$. Haematol. 2020, 190, 185-188. [CrossRef] [PubMed]

5. Schulze-Koops, H.; Krueger, K.; Vallbracht, I.; Hasseli, R.; Skapenko, A. Increased risk for severe COVID-19 in patients with inflammatory rheumatic diseases treated with rituximab. Ann. Rheum. Dis. 2021, 80, e67. [CrossRef] [PubMed]

6. Avouac, J.; Airó, P.; Carlier, N.; Matucci-Cerinic, M.; Allanore, Y. Severe COVID-19-associated pneumonia in 3 patients with systemic sclerosis treated with rituximab. Ann. Rheum. Dis. 2021, 80, e37. [CrossRef] [PubMed]

7. Monti, S.; Balduzzi, S.; Delvino, P.; Bellis, E.; Quadrelli, V.S.; Montecucco, C. Clinical course of COVID-19 in a series of patients with chronic arthritis treated with immunosuppressive targeted therapies. Ann. Rheum. Dis. 2020, 79, 667-668. [CrossRef] [PubMed]

8. Yan, K.; Rawle, D.J.; Le, T.T.; Suhrbier, A. Simple rapid in vitro screening method for SARS-CoV-2 anti-virals that identifies potential cytomorbidity-associated false positives. Virol. J. 2021, 18, 123. [CrossRef] [PubMed]

9. The Israeli Ministry of Health: The Protocol of Convalscent Plasma in COVID-19 Patient. Available online: https://www.health. gov.il/English/Topics/Diseases/corona/Pages/press-release.aspx (accessed on 25 June 2021).

10. Hueso, T.; Pouderoux, C.; Péré, H.; Beaumont, A.-L.; Raillon, L.-A.; Ader, F.; Chatenoud, L.; Eshagh, D.; Szwebel, T.-A.; Martinot, M.; et al. Convalescent plasma therapy for B-cell-depleted patients with protracted COVID-19. Blood 2020, 136, $2290-2295$. [CrossRef] [PubMed]

11. Cao, W.; Liu, X.; Bai, T.; Fan, H.; Hong, K.; Song, H.; Han, Y.; Lin, L.; Ruan, L.; Li, T. High-dose intravenous immunoglobulin as a therapeutic option for deteriorating patients with coronavirus disease 2019. In Open Forum Infectious Diseases; Oxford University Press: Oxford, UK, 2020; Volume 7, p. ofaa102.

12. Dufort, E.M.; Koumans, E.H.; Chow, E.J.; Rosenthal, E.M.; Muse, A.; Rowlands, J.; Maxted, A.M.; Rosenberg, E.S.; Easton, D.; Udo, D.; et al. Multisystem inflammatory syndrome in children in New York State. N. Engl. J. Med. 2020, 383, 347-358. [CrossRef] [PubMed]

13. Heidary, F.; Gharebaghi, R. Ivermectin: A systematic review from antiviral effects to COVID-19 complementary regimen. J. Antibiot. 2020, 73, 1-10. [CrossRef] [PubMed] 